\title{
What Does It Take To Get Your Foot In The Door?
}

\section{Mark Boehm}

Mark A. Boehm, "What Does It Take To Get Your Foot In The Door?," Proc. SPIE 0978, 1988 Intl Conf on Education in Optics, (27 April 1989); doi: $10.1117 / 12.948606$

Event: 32nd Annual International Technical Symposium on Optical and Optoelectronic Applied Science and Engineering, 1988, San Diego, CA, United States 
What does it take to get your foot in the door?

Mark A. Boehm

California Laser, A Laser Photonics Company

5145 Avenida Encinas, Carlsbad, CA 92008

\section{ABSTRACT}

Are unlimited employment opportunities available for graduates of optic and electrooptic programs? There should be some controls to assure quality in training personnel in electro-optics. Does this control eliminate the opportunities for fresh, start-up programs? Is the present number of established programs sufficient for training all of industry's needs?

\section{INTRODUCTION}

At the 1987 SPIE Technical Symposium on Optics, Electro-optics, and Imaging in orlando, Florida, Mr. Robert E. Fischer and Mr. R. Barry Johnson found themselves in an audience of eleven prospective graduates of an electro-optic program from Houston, Texas. These eleven students, one of which was myself, were all there with one goal in mind. The goal was to find employment in the field of electro-optics.

Mr. Fischer and Mr. Johnson were in awe at the enthusiasm of these young men and women, and were concerned that these students were in such dire straits for employment opportunities. If the employment scene is so ideal, then why were these eleven young people canvassing this conference in search of employment?

\section{COMMON MISCONCEPTIONS}

Many in industry paint the rosy picture that any student graduating with a degree in optics, electro-optics, or laser physics is immediately snatched by employers before the ink is dry on the sheepskin. Likewise, it seems to be common practice for universities to boastfully announce to degree seeking applicants that once a degree is earned, jobs are guaranteed. Are these true perceptions of the market? Many reports project shortages of engineers in the future. And yet, each month the SPIE "E-O Report" has at least one to two pages of degreed applicants looking for employment. Three-quarters of these listings are recent or soon-to-be grads.

\section{WHAT IS IT GOING TO TAKE?}

Mr. Fischer inquired as to the outlets the students had used to seek employment. It was stated that the usual means were undertaken: journal and newspaper listings, word of mouth from past graduates and just cold-call letters to employers. If the conventional and even non-conventional methods were being exhausted, then why were these minds not being employed? Why was industry overlooking the untapped potential that lies with these graduates? Many theories abound. Some say you must graduate from a prestigious university. Others say you must possess a 4.0 grade point average, and yet others say you must know someone on the inside. After one muddles through the employment maze, just what does the final selection process rely on?

There is no doubt that a degree from a reputable university is a definite advantage. Is it essential to graduate from an MIT or a University of Rochester to be employable? it a "MUST" or just a "PLUS" to possess their golden scroll? What about all the other programs throughout the United states? Are there too many of them? What about their graduates? What are the chances when competing against graduates of the renowned universities?

\section{NO SIMPLE SOLUTIONS}

There needs to be concern for the quality of laser, electro-optic and optic programs from the technical training level through graduate studies. of course, quality is the goal of all involved. Must we discriminate against the newer, less established programs? What will it take for smaller programs to be recognized? These smaller programs may be just as well suited for industry's needs. With limited grants and enrollment quotas, there is a significant reduction in the number of students being educated at established institutions. 
If state governments and local industry are willing to support a program, who is to say a university cannot establish a degree program! The depth of the program may not be of the same caliber as an established institution, but in time, it may well be. Besides, are applicants' evaluations made on their personal achievements or are these being overshadowed by the name of the institution that has affixed its seal on the sheepskin? One must ask, "Are the universities getting the jobs or are the graduate's qualifications?".

All a graduate asks for is a fair shot at a position. One's personality or capacity cannot be fully evaluated from a school's reputation. Nor can a two dimensional piece of paper do justice to the potential of an up-and-coming engineer. When the potential of a new grad is realized, the results can be profitable for all involved. There is unlimited energy and ability with new graduates, whether they be from an established institution or from a small college.

\section{WHERE THE RESPONSIBILITY LIES}

Once a program has begun, how can one gain the recognition to get recruiters on campus? With university budgets getting slimmer, what can we do to help promote smaller programs? Societies such as SPIE need to accent awareness that openings should not be based on the educational facility one has been reared, but rather on qualifications for the position. It is up to each and every one of us to make the outside world aware that qualified personnel can be found in the most remote environments. Everyone has been in the position of being a new hire. It is our responsibility to the future of industry and societies such as SPIE to open our eyes.

\section{CONCLUSION}

There is true, untapped, highly qualified potential flowing throughout the nation. Regardless of what institution they have evolved from, graduates need to be given a chance. These students are left without an answer to the question, "What does it take to get your foot in the door?". 